\title{
Effects of a herbicide and copper mixture on the quality of marine plankton
}

\author{
Valentina Filimonova ${ }^{\mathrm{a}, \mathrm{b}, \mathrm{c}, *}$, Marleen De $\operatorname{Troch}^{\mathrm{c}}$, Fernando Gonçalves ${ }^{\mathrm{b}}$, João C. Marques ${ }^{\mathrm{a}}$, \\ Sérgio M. Marques ${ }^{\mathrm{b}}$, Ana M.M. Gonçalves ${ }^{\mathrm{a}, \mathrm{b}}$, Frederik De Laender ${ }^{\mathrm{d}}$ \\ a IMAR-CMA \& MARE, Faculty of Science and Technology, University of Coimbra, 3004-517 Coimbra, Portugal \\ ${ }^{\mathrm{b}}$ Department of Biology \& CESAM, University of Aveiro, 3810-193 Aveiro, Portugal \\ ${ }^{\mathrm{c}}$ Faculty of Science, Biology Department, Marine Biology, Ghent University, Krijgslaan 281-S8, B-9000 Gent, Belgium \\ ${ }^{\mathrm{d}}$ Research Unit in Environmental and Evolutionary Biology, Biology Department, University of Namur, Rue de Bruxelles 61, BE-5000 Namur, Belgium
}

\section{A R T I C L E I N F O}

\section{Keywords:}

Food quality

Generalized linear model

Plankton

Species sensitivity

Biomarkers

Fatty acids

\begin{abstract}
A B S T R A C T
Pesticides and metals are often used in agriculture and are therefore often simultaneously discharged to nearby estuarine and marine areas. The effects of this organic-inorganic chemical mixture on food quality of aquatic organisms are currently unknown. In this study we test if a mixture of copper (inorganic) and the herbicide Primextra ${ }^{\circledR}$ Gold TZ (organic) affects the quality of the diatom Thalassiosira weissflogii and the copepod Acartia tonsa - two key species that fuel the local food-web. We quantified quality (i.e. energy content as food for the next trophic level) in terms of fatty acids, proteins and thiobarbituric acid reacting substances. We found nonadditive effects (positive and negative) of the metal-herbicide mixture on the diatom and copepod species. In general, nutritionally important biochemical parameters of Acartia tonsa were most sensitive to the chemical stressors.
\end{abstract}

\section{Introduction}

The amount of available biomass has important effects on ecosystem functions, as it drives the amount of food available in food webs. In plankton communities, low food quality of phytoplankton biomass leads to poor energy and nutrient transfer through the food web (Perhar and Arhonditsis, 2009).

Important indicators of quality (i.e. energy content as food for the next trophic level)are the fatty acids (FA), especially the essential ones (EFA), and proteins. The dietary protein content influences the biochemical composition of invertebrates and their growth rate and production. Fatty acids are the main components of lipids and fuel all metabolic systems. EFA belong to the group of polyunsaturated fatty acids (PUFA) and play a key role in the health and function of all animals at all trophic levels.

Chemical stressors can catalyze the production of reactive oxygen species, which may lead to the lipid peroxidation in organisms. Consequently, lipid peroxidation may severely change the nutritional quality by breaking down EFA. The measurement of thiobarbituric acid reacting substances (TBARS) content is the most common test to assess the lipid peroxidation and thus stress response but it is also used as one of the standardized parameters of food quality (Huss, 1995).

Most ecotoxicological studies expose species to single doses of chemical stressors (Chen et al., 2015). Few studies are focused on mixtures of stressors from one chemical group (e.g. organic-organic or inorganic-inorganic) (Hanazato, 2001). However, even fewer studies have reported on mixtures of contaminants from different chemical groups (e.g. organic and inorganic). Such studies are urgently needed to better predict the changes that can be expected from the exposure of aquatic communities to environmental stress (Filimonova et al., 2016a). The simultaneous presence of organic and inorganic contaminants is especially relevant for estuarine and marine areas with intensive agricultural activities, because the discharge of pesticides and metals can be substantial in these areas (Gonçalves et al., 2016).

At present, according to the information obtained from agricultural cooperatives of Mondego valley located in West Atlantic coast of Portugal, the herbicide Primextra Gold TZ is one of the 20 best-selling herbicides in Portugal, being widely used in corn fields, whereas copper is in general one of the main constituents of fungicides, herbicides, molluscides, and pesticides (Filimonova et al., 2016b; Gonçalves et al., 2016; Neves et al., 2015).

Copper (II) sulphates pentahydrate belongs to the group of

\footnotetext{
Abbreviations: FA, fatty acids; EFA, essential fatty acids; EPA, eicosapentaenoic acid; DHA, docosahexaenoic acid; PUFA, polyunsaturated fatty acids; TBARS, thiobarbituric acid reacting substances; GLM, generalized linear model; FAMEs, fatty acid methyl esters; ROS, reactive oxygen species

* Corresponding author at: University of Aveiro, Department of Biology \& CESAM, 3810-193 Aveiro, Portugal.

E-mail addresses: valentikina.filimonova@ua.pt, valentina.filimonova@ugent.be (V. Filimonova), Marleen.DeTroch@ugent.be (M. De Troch), fjmg@ua.pt (F. Gonçalves), jcmimar@ci.uc.pt (J.C. Marques), sergio.marques@ua.pt (S.M. Marques), anamartagoncalves@ua.pt (A.M.M. Gonçalves), frederik.delaender@unamur.be (F. De Laender).
} 
fungicides. The Portugese market is largely dominated by fungicides. In the last 10 years their consumption has been decreasing smoothly and by 2015 reached $5193 \mathrm{t}$ of active ingredients (a.i.). being still 1.5 times higher than in 1992 and 2.5 times higher than the herbicide consumption in 2015 (http://www.fao.org/faostat).

Primextra ${ }^{\circledast}$ Gold TZ (Syngenta AG) consists of two main a.i., 30.2\% $(\mathrm{w} / \mathrm{w})$ S-metolachlor and $\mathbf{1 7 . 7 5 \%}(\mathrm{w} / \mathrm{w})$ terbuthylazine (TBA). It contains as well a residual percentage of coadjuvant substances that are supposed to be inert (Filimonova et al., 2016b; Neves et al., 2015). According to groundwater ubiquity score (GUS) that estimates the pesticide's potential to move towards groundwater and ranks their leaching potential from extremely low (below 0$)$, via low $(0-1.8)$ and moderate $(1.8-2.8)$ to high (above 2.8 ) ones, metolachlor and TBA have a high leaching potential: GUS index of 3.5 and 3.1, respectively. Therefore, they are expected to contaminate aquatic ecosystems. In addition, these compounds are relatively hydrophobic and have a high potential for bioaccumulation ( $\log \mathrm{K}_{\mathrm{ow}}=3.40$ ), which indicates their possible accumulation in aquatic organisms and therefore finally of their bioamplification in the food chains (Cruzeiro et al., 2016; Gustafson, 1989). A recent study revealed the presence of both active ingredients of Primextra ${ }^{\circledR}$ Gold TZ in the Mondego River estuary (Cruzeiro et al., 2016). Although the amount of TBA was lower than the established legislation value of $0.100 \mu \mathrm{g} / \mathrm{L}-0.088 \mu \mathrm{g} / \mathrm{L}$ (in winter) metolachlor exceeded this value $-0.266 \mu \mathrm{g} / \mathrm{L}$ (in spring) was obtained (Cruzeiro et al., 2016).

Copper sulphate is known to be toxic to invertebrates, i.e. rotifers, cladocerans and copepods and above a specific concentration - to fish including economically valuable species such as salmonids, cyprinids and catfish (Abdel-Tawwab et al., 2007). At higher than essential amounts copper negatively influences on numerous important processes, including metabolism of fatty acid and protein synthesis. Metolachlor as well inhibits the biosynthesis of several crucial molecules including proteins and very long chain fatty acid that are essential for all living organisms, whereas TBA inhibits the photosynthesis at photosystem II (Filimonova et al., 2016b). Only a few studies analysed the toxic and biochemical effects of Primextra ${ }^{\circledR}$ Gold TZ on aquatic species: e.g. marine bivalves Cerastodermaedule and Scrobicularia plana (Gonçalves et al., 2016), freshwater zooplanktonic species Daphnia longispina (Neves et al., 2015) and freshwater fish species Clarias gariepinus and Clarias albopunctatus (Asomba and Ugokwe, 2015; Nwani et al., 2014). Therefore, it is essential to study the toxicological and biochemical effects of this herbicide on other non-target species (Gonçalves et al., 2016) especially in combination with inorganic substances, i.e. metals, such as copper.

In order to clarify whether this combination will lead to additive or non-additive effects, in the present study, we analysed the effects of two different chemical stressors on the FA, EFA, protein and TBARS contents, using planktonic species at two trophic levels. We considered the herbicide Primextra ${ }^{\circledR}$ Gold TZ and the metal copper, i.e. copper (II) sulphates pentahydrate, both individually and in an equitoxic mixture. We selected two plankton species(one primary producer, one consumer) that are well-known test species in marine ecotoxicology: the marine diatom Thalassiosira weissflogii and the estuarine copepod Acartia tonsa (one of the most abundant copepod species in the Mondego estuary (Gonçalves et al., 2010)).

In the Mondego estuary diatoms are one of the dominating phytoplankton groups (Flindt et al., 1997) therefore in this study the diatom T. weissflogii was chosen as one of the main primary producer species.

The main aims of this study were to determine: (1) whether there is an additive (without interaction of chemicals) or non-additive (with interaction of chemicals) effect of a relevant chemical mixture on the FA, EFA, protein and TBARS contents (as proxy for energy content or food quality for the next trophic level) of selected phytoplankton and zooplankton species, and (2) how this mixture differentially affects different trophic levels.

\section{Materials and methods}

\subsection{Cultures maintenance}

Culture conditions and its maintenance were followed as described by Filimonova et al. (2016b).

Acartia tonsa (Copepoda, Calanoida) was sampled in the south arm of Mondego estuary $\left(40^{\circ} 08^{`} \mathrm{~N}, 8^{\circ} 50^{\circ} \mathrm{W}\right)$ near the Pranto river, where it was found in high abundance (Gonçalves et al., 2010). The Mondego estuary is a tidal estuary located near Figueira da Foz city on the west coast of Portugal.

Copepods were sampled with horizontal subsurface tows with a bongo net, placed to the $2.5 \mathrm{~L}$ flasks filled with the estuarine water and transported to the laboratory (Gonçalves et al., 2012). Adults of $A$. tonsa were separated from other species and moved to prepared $10 \mathrm{~L}-$ aquaria at a concentration of 1 individual per $10 \mathrm{~mL}$ of medium for further maintenance and reproduction (Rippingale and Payne, 2001). Aquaria were supplied with gentle aeration system. Filtrated $(1.2 \mu \mathrm{m}$ pores: to exclude the possibility of nanoplankton penetration) natural seawater diluted with distilled water to a salinity of 13-15 psu was used as medium. These values reflected the salinity found in the sampling site and allowed to maintain the successful reproduction and growth of A. tonsa. The medium renewal (30\% from the total volume) and measurements of dissolved $\mathrm{O}_{2}(\%)$ were applied regularly. Feeding with the diatom T. weissflogii $\left(2 \times 10^{4}\right.$ cells $\left./ \mathrm{mL}\right)$ was done3 times a week. A Neubauer chamber was used to count the algae cells. Adult organisms, grown during 14 days from the first cohort of nauplii were used for the bioassays.

The diatom species Thalassiosira weissflogii was acquired from the Scottish Marine Institute (Dunbeg, PA37 1QA, UK; strain number 1085/ 18). It was cultured with the Guillard's $\mathrm{f} / 2$ medium with a salinity of 30 psu, without EDTA [adapted from Rippingale and Payne, 2001] that was used as well for algae dilution. A renew of algae culture was done weekly.

Zooplankton and phytoplankton culture maintenance was conducted with a $16 \mathrm{~h}$ light and $8 \mathrm{~h}$ dark light photoperiod and at a temperature of $20 \pm 2{ }^{\circ} \mathrm{C}$.

\subsection{Population microcosm bioassays for the determination of the effect on the quality of the diatom and copepod species}

Microcosm bioassays for the determination of the effect on the quality of studied species were conducted to determine changes in their FA profiles, EFA, protein and TBARS contents after exposure to the herbicide Primextra Gold TZ and the metal copper (II) sulphates pentahydrate individually and in equitoxic mixture. These bioassays were performed according to Filimonova et al. (2016b) under the same laboratory conditions described above for culture maintenance.

The diatom $T$. weissflogii and the copepod A. tonsa were exposed in four experimental treatments: (1) a negative control - CTL, consisting of uncontaminated culture medium; (2) a low level of each toxicant - C1; (3) an intermediate level - C2 and (4) a high level - C3 (Table S1, Supplemental data).

These treatments were chosen in view of their negative effect (C1, C2, C3 caused $10 \%, 20 \%$ and $50 \%$ effect, respectively) on the relative growth rate of $T$. weissflogii (i.e. growth inhibition) and the relative survival of $A$. tonsa (i.e. immobilized individuals) after exposure to the equitoxic mixture of contaminants during $96 \mathrm{~h}$ and $48 \mathrm{~h}$ bioassays respectively that were performed according to Filimonova et al. (2016b).

For both species, all treatments were replicated three times in bioassays to conduct further FA analysis and five times in bioassays to conduct further TBARS and protein contents determination. The duration of bioassays for further TBARS and protein content determination was $96 \mathrm{~h}$, whereas for further FA analyses -7 days. Exposures of both species were performed in glass (pesticide and mixture bioassays) and plastic (metal bioassays) beakers: copper is able to bind with silica 
constituting the chemical structure of the glass, therefore plastic flasks were used in bioassays with copper; the glass dishes are typically used when the test material is unknown (Rand, 1995). That was the case for bioassays with the herbicide formulation and its mixture with the metal.

Bioassays with $T$. weissflogii were carried out in flasks with the final volume of the medium $40 \mathrm{~mL}$, i.e. the Guillard's f/2 medium with a salinity of 30 psu. Initial cell density was $10^{4}$ cells / mL.At the end of each bioassay $3.6 \times 10^{6}$ cells / $\mathrm{mL}$ of diatom were counted in each replicate that was then concentrated and stored frozen at $-80^{\circ} \mathrm{C}$ for further biochemical analyses. Neubauer haemocytomer was used to calculate the cell density. For further FA analyses cells were concentrated on GF/F Whatman filters, for the TBARS and protein contents measurementthe diatom cells were separated from the culture medium by centrifugation $\left(4^{\circ} \mathrm{C}, 4000 \mathrm{rpm}, 10 \mathrm{~min}\right)$.

Bioassays with $A$. tonsa were done in vials with a final volume of $2500 \mathrm{~mL}$ with 250 individuals per replicate for further FA analyses and of $5000 \mathrm{~mL}$ with 500 individuals per replicate for further TBARS and protein contents determination. Each flask was connected to a gentle aeration system. A. tonsa were fed daily with $T$. weissflogii cells in the exponential growth phase at a concentration of $2 \times 10^{4}$ cells $/ \mathrm{mL}$ and moved to new test solutions every third day. When feeding the copepod species with the diatom culture the salinity was adjusted back to 13-15 psu adding distilled water to the experimental flasks. This was a very small volume and had no substantial influence on the final volume. At the end of each bioassay for further FA analyses 60 individuals per replicate were concentrated on GF/F Whatman filters and stored frozen at $-80^{\circ} \mathrm{C}$. At the end of each bioassay for further TBARS and protein contents determination 250 individuals per replicate were separated manually without medium and stored frozen at $-80^{\circ} \mathrm{C}$. The further TBARS and protein analyses were performed with individuals of the same flask in each bioassay.

\subsection{Population microcosm bioassays for a comparison of the effects between trophic levels}

In order to compare the effects between trophic levels, both the primary consumer $A$. tonsa and the primary producer $T$. weissflogii were exposed to the same test conditions and to the same levels of contaminants.

Biochemical analyses of the species required the collection of live organisms at the end of each bioassay. Therefore, the contaminant's concentrations applied to $A$. tonsa (Table S1) were used for both species (Table S2, Supplemental data)".

Due to the low cell density of diatoms at the end of each bioassay the separation of diatom from the culture medium was possible only with the GF/F Whatman filter. Therefore, the samples were stored only for further FA analysis.

\subsection{Biochemical analyses}

Analyses of fatty acids including essentials fatty acids were followed as described by Filimonova et al. (2016b).

The initial step was the extraction of total lipids of study species and their methylation to fatty acid methyl esters (FAMEs) that were performed with a modified 1-step derivatisation method from De Troch et al. (2012) and Gonçalves et al. (2012). The internal standard of methylnonadecanoate C19:0 fatty acid (Fluka 74208) was added to each sample for the quantification of FA. The FAMEs thus obtained were analysed using a gas chromatograph (HP 6890 N GC) coupled to a mass spectrometer (HP 5973).

All samples were run in split4 mode with a $0.25 \mu \mathrm{L}$ injection per run at an injector temperature of $250{ }^{\circ} \mathrm{C}$, using a HP88 column (Agilent $\mathrm{J}$ \& W; Agilent Co., USA) with a He flow of $1.5 \mathrm{~mL}$ min-1. The oven temperature was programmed at $50^{\circ} \mathrm{C}$ for $2 \mathrm{~min}$, followed by a ramp of $25{ }^{\circ} \mathrm{C} \mathrm{min}{ }^{-1}$ to $75{ }^{\circ} \mathrm{C}$, then a second ramp at $2{ }^{\circ} \mathrm{C} \mathrm{min}^{-1}$ to $230{ }^{\circ} \mathrm{C}$ with a final 14 min hold.

FAMEs were identified by comparison with the retention times and mass spectra of authentic standards and available ion spectra in Famedb23 (composed in the Marine Biology research group) and WILEY mass spectral libraries. The analyses of FAMEs were performed with the software Agilent MSD Productivity ChemStation. External (Supelco 37 Component FAME Mix, Supelco \# 47885, Sigma-Aldrich,

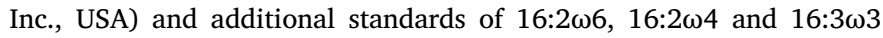
(Larodan Fine Chemicals) were used to quantify the individual FAMEs.

A linear regression was applied to the chromatographic peak areas and corresponding known concentrations of the standards (from 100 to $800 \mu \mathrm{g} / \mathrm{mL}$ ) to define the quantification function of each FAME.

The used shorthand fatty acids notations of the form X:Y $\mathrm{XZ}$ denote the following: $\mathrm{X}$ is the number of carbon atoms, $\mathrm{Y}$ is the number of double bonds, and $\mathrm{Z}$ is the position of the double bond closest to the terminal methyl group (De Troch et al., 2012; Filimonova et al., 2016b).

Samples of copepod and diatom for further TBARS and protein contents determination were homogenized and sonicated respectively at $4{ }^{\circ} \mathrm{C}$ in $50 \mathrm{mM} \mathrm{NaH}{ }_{2} \mathrm{PO}_{2} / \mathrm{Na}_{2} \mathrm{HPO}_{4}$ buffer, $\mathrm{pH} 7.0$, containing $0.1 \%$ Triton X-100 and then centrifuged at $15,000 \mathrm{G}$ for $10 \mathrm{~min}$ at $4{ }^{\circ} \mathrm{C}$. The supernatant 1 of each sample was divided in two aliquots, one for protein content determination and the other for determining the TBARS' content. For TBARS the supernatant 1 of each sample was treated with $10 \%$ trichloroacetic acid and then centrifuged at 10,000G for $1 \mathrm{~min}$ at room temperature. Supernatant 2 was treated with $1 \%$ thiobarbituric acid and then boiled for $10 \mathrm{~min}$. After cooling it was centrifuged a second time at $10,000 \mathrm{G}$ for $1 \mathrm{~min}$ at room temperature.

Supernatant 3 was taken and its absorbance measured at 535 nmusing a microplate reader LabSystems Original Multiskan EX and a molar extinction coefficient of $1.56 \times 10^{5} \mathrm{M}^{-1} \mathrm{~cm}^{-1}$ was used to calculate TBARS concentration. The values were expressed as nanomoles of malondialdehyde (MDA, one of the main co-products of lipid peroxidation with 2-thiobarbituric acid) per milligram of protein (Buege and Aust, 1978).

Protein concentration was measured in supernatant 1 by the Bradford method with Coomassie Brilliant Blue G-250 (Bradford, 1976) and using $\Upsilon$-globulin bovine as a standard. The protein assay was performed using a microplate reader LabSystems Original Multiskan EX at $595 \mathrm{~nm}$ and expressed as milligrams per milliliter.

One-way analysis of variance (ANOVA) was applied to the biochemical parameters, i.e. protein and TBARS contents, that were significantly predicted by the contaminant/s to test significant differences among treatments. The Dunnett's multiple comparison test was further performed to determine the significant differences between contaminated treatments and uncontaminated treatment, i.e. the control. The used level of significance was of 0.05 . Prior to the analysis, the data were checked to meet the assumptions of normality (Shapiro-Wilk test) and homoscedasticity (Levene's test).

\subsection{Modelling of the data}

Generalized Linear Models can be used to test the presence or absence of a non-additive effect. To achieve the main aims of the study we fitted generalized linear models with interaction $\left(\mathrm{GLM}_{\mathrm{i}}\right)$ and without interaction $\left(\mathrm{GLM}_{\mathrm{n} / \mathrm{i}}\right)$ terms to experimentally observed responses of biochemical composition to the single substances and the mixture.

The further comparison of their Akaike Information Criterions (AICs) was used to evaluate the predictive capacity of each model and allowed us to test if effects were additive or not. A lower AIC was interpreted as a better trade-off between predictive capacity and model complexity.

Thus, a GLM with gamma distribution and inverse link function (model 1) was used to estimate the effect of the chemical mixture on the quality of the planktonic species with biochemical parameters: FA, EFA, TBARS and protein contents as response variables and the treatments of copper (II)sulphates pentahydrate and the herbicide Primextra as 
predictors.

The presence of non-additive effects was tested via applying the GLM with interaction $\left(\mathrm{GLM}_{\mathrm{i}}\right)$ and without interaction of contaminants $\left(\mathrm{GLM}_{\mathrm{n} / \mathrm{i}}\right)$.

$B P_{i}=\beta_{0}+\beta_{1} \times T_{C u S P, i}+\beta_{2} \times T_{P r, i}(\operatorname{model} 1, \mathrm{GLMn} / \mathrm{i})$

$B P_{i}=\beta_{0}+\beta_{1} \times T_{C U S P, i}+\beta_{2} \times T_{P r, i}+\beta_{3} \times T_{C u S P, i} \times T_{P r, i}(\operatorname{model} 1, \mathrm{GLMi})$

(model 1)

$B P_{i}$ represents the biochemical parameter (FA, EFA, TBARS or protein contents) at the concentration $i$ of the contaminant; $T_{C u S P, i}$ and $T_{P r, i}$ are treatments of copper (II) sulphate pentahydrate and Primextra ${ }^{\circledR}$ at the concentration $i$ (Table S1); $\beta_{0}$ and $\beta_{1} / \beta_{2} / \beta_{3}$ are the intercept and the related slopes, respectively.

Homogeneity of model residuals was inspected by plotting the standardized residuals versus the predicted values. The goodness of the model fit was estimated by plotting the observed values versus the predicted values (Zuur et al., 2009).

To compare the effects of the chemical mixture between the two different trophic levels, we made two models:

(1) the GLM model 1, where for each species equal levels of contaminants (Table S2)were predictors and species FA profiles were dependent variables;

(2) the GLM model 2, where the saturated FA (SFA) and polyunsaturated FA (PUFA) of the copepod species were response variables and the SFA and PUFA of the diatom species were predictors.

$F A_{A t, i}=\beta_{0}+\beta_{1} \times S F A_{T w, i}+\beta_{2} \times P U F A_{T w, i}$

(model 2)

$F A_{A t}$ represents the response of either saturated FA or polyunsaturated FA of the copepod $A$. tonsa at the concentration $i$ of the contaminant, $S F A_{T w, i} / P U F A_{T w, i}$ are saturated / polyunsaturated FA of the diatom T. weissflogii at the concentration $i$ of the contaminant, $\beta_{0}$ and $\beta_{1} / \beta_{2}$ are the intercept and the related slopes.

FA data of the copepod species were $\log 10$ - transformed to meet the assumptions of generalized linear model regarding homoscedasticity, i.e. homogeneity of model residuals was tested by plotting the standardized residuals versus the predicted values (Zuur et al., 2009). The goodness of the model fit were tested by plotting the observed values versus the predicted values (Zuur et al., 2009).

All calculations were performed in $\mathrm{R}$ ver. 3.2.2, using RStudio ver. 0.99 .489 and the packages lattice, mgcv, nlme.

\section{Results}

\subsection{The effect of chemical mixture on the quality of the diatom and copepod species}

We found non-additive effects (both positive and negative) of the chemical mixture on most biochemical parameters. The GLM $_{i}$ model predicted better the essential FA of the copepod Acartia tonsa and the TBARS and protein contents of both species than the model without interaction $\left(\mathrm{GLM}_{\mathrm{n} / \mathrm{i}}\right)$. Only for the total FA profile of both species and for the essential FA data of the diatom T. weissflogii a lower AIC value for the $G_{L} M_{n / i}$, suggesting that interactions were not improving the predictive capacity (Fig. 1), was reported. Plots indicating the goodness of the model fit are presented at Fig. S1 (Supplemental data).

Modelling results revealed that the treatments affected most of the biochemical parameters only for the copepod species. For the diatom species, only a few parameters had significant effects (Table 1).

Due to the used link function, a negative value of coefficient refers to the increase of content of the biochemical parameter and a positive value to its decrease in the presence of the related contaminant.

Thus, the quality of the diatom species was significantly predicted by the metal copper and the equitoxic mixture of contaminants in terms of TBARS and protein contents respectively $(\mathrm{p}<0.05)$, Table 1 and Figs. 2a, 3a). The latter parameter indicated the presence of the lipid peroxidation in $T$. weissflogii. However, the single treatments of the herbicide Primextra ${ }^{\circledR}$ applied to the diatom did not reveal any significant influence on its quality.

An opposite trend was revealed for $A$. tonsa: the herbicide Primextra $^{\circledR}$ Gold TZ affected significantly all nutritionally important biochemical parameters ( $\mathrm{p}<0.05$, Table 1 ) by reducing the amount of FA, EFA and protein (Figs. 4b, d; 3b) and increasing TBARS content (Fig. 2b), whereas the single treatments of the metal copper significantly predicted only the total FA and EFA contents in the copepod species ( $\mathrm{p}<0.05$, Table 1)in terms of a decrease of its amount (Fig. 4a, c). The single treatments of the herbicide (Fig. 2b) and the equitoxic mixture of copper and herbicide (Fig. 2c) significantly impacted the TBARS content proving the interference in the process of lipid peroxidation in the copepod $A$. tonsa.

\subsection{Comparison of the effects of chemical mixture between trophic levels}

An additive effect of the chemical mixture was revealed for the total FA profiles of both species (Fig. 5). However, a non-additive effect was revealed for the essential FA of both primary producer and primary consumer. For both species, the AIC suggested the model without interactions $\left(\mathrm{GLM}_{\mathrm{n} / \mathrm{i}}\right)$ for the total FA profile's data, and the model with interactions $\left(\mathrm{GLM}_{\mathrm{i}}\right)$ for the essential FA data (Fig. 5). Plots indicating the goodness of the models fit for the models 1 and 2 are presented in the supplemental material section as well (Figs. S2 and S3, respectively).

The GLM with inverse link function fitted to the biochemical data of each species exposed to equal levels of contaminants revealed no significant impact on the total FA profile and essential FA of the primary producer diatom T. weissflogii, whereas in the case of the primary consumer copepod A. tonsa, significant effects of the herbicide Primextra $^{\circledast}$ and metal copper on these parameters were reflected in a decrease of their amount (Table 2, Fig. 4).

An output of the model 2 indicated that both saturated and polyunsaturated fatty acids of the primary producer T. weissflogii significantly correlate with saturated fatty acids of the primary consumer A. tonsa. However, no relationship was observed between FA profile of the diatom species and PUFAs of the copepod A. tonsa (Table 2).

\section{Discussion}

\subsection{The effect of the chemical mixture on the quality of the diatom and copepod species}

Studies examining the influence of the organic and inorganic contaminants on the nutritional quality of planktonic species are very scarce. Baker et al. (2016) revealed that simultaneous exposure to glyphosate herbicide and nutrients (ammonium nitrate and phosphoric acid) led to the decline in edible carbon content and thus in dietary quality of phytoplankton and zooplankton communities. This effect was not found after exposure to only the herbicide.

To the best of our knowledge, the current study is the first that determines the interaction effect of the organic and inorganic toxicant's mixture on the species quality. The overall results of our study demonstrated that non-additive effects allow a better prediction of the mixture effect of the herbicide Primextra ${ }^{\circledR}$ and the metal copper on the nutritional quality, compared to a model that assumes purely additive effects.

It is noteworthy that studies about the interaction effect of organic and inorganic contaminants on non-target species are scarce in the literature and are aimed mostly at measuring species growth, survival or reproduction (Chen et al., 2015; Filimonova et al., 2016a; Klerks and Moreau, 2001).

Herbicides and metals both adversely affect the same biological 


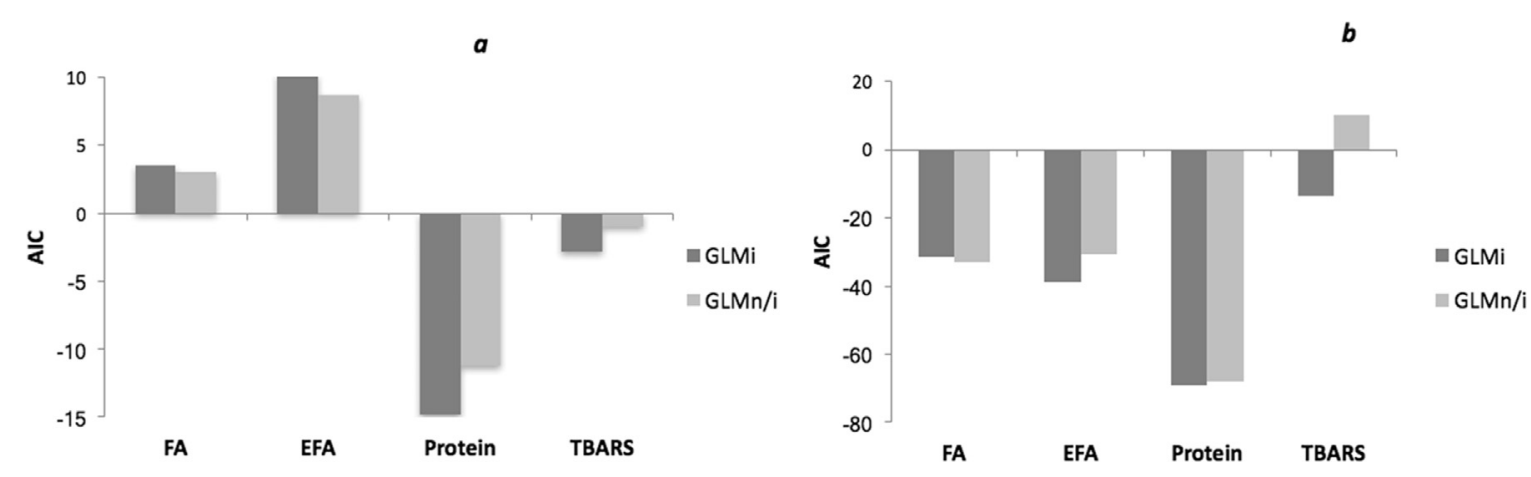

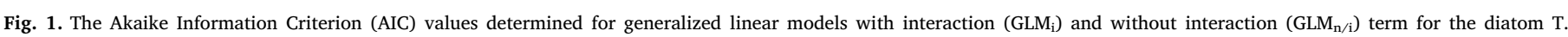

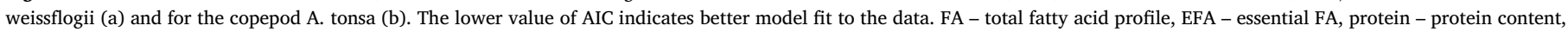
TBARS - thiobarbituric acid reacting substances content.

component: EFA, via interactions of these contaminants to various biochemical processes, i.e. gluthatione peroxidase's inhibition that leads to peroxidation of EFA's membranes, inhibition of FA elongation and $\omega 3, \omega 6$ - desaturation processes; and creation of new adverse biochemical reactions, i.e. production of reactive oxygen species (ROS) that enter into a reaction with EFA molecules (Cohen et al., 1993; Robert et al., 2007). PUFA, including EFA are almost exclusively synthesized by algae and plants. Diatoms contain much EFA, which may allow the effects of both chemicals to be added up. The other reason may be the presence of the cell wall in the algae cell structure that plays an important role in the defence responses against potential stressors (Keegstra, 2010). Animals can convert one form of PUFA to another through elongation and desaturation, but very few can synthesize PUFA de novo (Brett and Müller-Navarra, 1997). Planktonic calanoid copepods (i.e. our study species $A$. tonsa) have limited ability of FA bioconversion as they lack the necessary enzymes to produce significant amounts of PUFA (De Troch et al., 2012). Therefore, they have a limited amount of EFA, and thus the effects were non-additive.

Most of nutritionally important biochemical parameters of the investigated planktonic species were significantly affected by at least one of the chemical stressors. This is in accordance with other studies where biochemical composition of aquatic organisms was affected by herbicides or metals.

The effect on protein content was revealed after exposure of aquatic species from different trophic levels to metal copper (Pytharopoulou et al., 2013), to Metolachlor (Martins et al., 2011), to triazine herbicides (El-Sheekh et al., 1994) and to the combination of the metal copper and chloroacetanilide herbicide applied to phytoplankton species (Lu et al., 2015). The latter is in agreement with our result that the metal-herbicide mixture significantly predicted protein content of the diatom species.

TBARS content as well revealed to be affected by copper (Bazihizina et al., 2015) and triazine herbicides (Velisek et al., 2014). In our case TBARS content was significantly predicted by the metal copper in the case of the diatom $T$. weissflogii and by the herbicide Primextra ${ }^{\circledR}$ in the case of the copepod A. tonsa. The metal copper and two main active ingredients of the herbicide Primextra ${ }^{\circledR}$ : S-metolachlor and terbuthylazine, which belong to the groups of chloroacetanilide and triazine herbicides respectively induce reactive oxygen species (ROS). (Filimonova et al., 2016a, 2016b). ROS attack the polyunsaturated fatty acids (including the essential FA) producing secondary products such as hydroperoxides or their aldehyde derivatives, which inhibit the protein synthesis (Repetto et al., 2012). Among them are MDA molecules biomarkers of lipid $(\omega 3, \omega 6)$ peroxidation that is estimated by the

Table 1

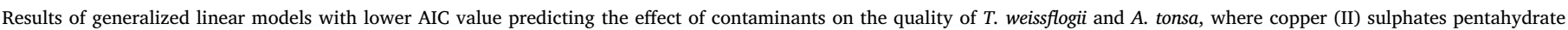

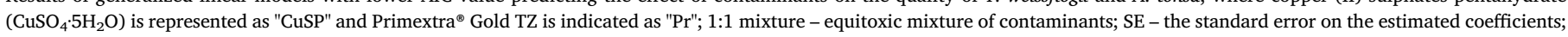
statistically significant values are in bold.

\begin{tabular}{|c|c|c|c|c|c|c|c|c|c|c|}
\hline $\begin{array}{l}\text { Biochemical } \\
\text { parameter }\end{array}$ & Predictor & Coefficients & SE & $\mathbf{t}$ & $\mathbf{p}$ & $\begin{array}{l}\text { Median deviance } \\
\text { of residuals }\end{array}$ & $\begin{array}{l}\text { Null deviance / } \\
\text { degrees of freedom }\end{array}$ & $\begin{array}{l}\text { Residual deviance / } \\
\text { degrees of freedom }\end{array}$ & AIC & Effect \\
\hline \multicolumn{11}{|l|}{ T. weissflogii } \\
\hline \multirow[t]{2}{*}{ FA } & CuSP & -.290 & 0.317 & -0.915 & 0.369 & -0.018 & $1.185 / 26$ & $0.989 / 24$ & 3.005 & additive \\
\hline & $\operatorname{Pr}$ & 24.200 & 16.299 & 1.485 & 0.151 & & & & & \\
\hline \multirow[t]{2}{*}{ EFA } & CuSP & -.062 & 0.300 & -0.208 & 0.837 & -0.024 & $1.498 / 26$ & $0.994 / 24$ & 8.985 & additive \\
\hline & $\operatorname{Pr}$ & 46.671 & 15.241 & 3.062 & 0.055 & & & & & \\
\hline \multirow[t]{3}{*}{ Protein } & CuSP & .652 & 0.743 & 0.878 & 0.385 & & & & & \\
\hline & $\operatorname{Pr}$ & 32.371 & 40.692 & 0.796 & 0.431 & 0.029 & $2.888 / 44$ & $1.471 / 41$ & -14.792 & non-additive \\
\hline & 1:1 mixture & -412.121 & 170.654 & -2.415 & 0.020 & & & & & \\
\hline \multirow[t]{3}{*}{ TBARS } & CuSP & -1.730 & 0.703 & -2.460 & 0.018 & & & & & \\
\hline & $\operatorname{Pr}$ & -69.870 & 39.558 & -1.766 & 0.085 & -0.017 & $2.050 / 44$ & $1.727 / 41$ & -2.816 & non-additive \\
\hline & 1:1 mixture & 312.731 & 162.984 & 1.919 & 0.062 & & & & & \\
\hline \multicolumn{11}{|l|}{ A. tonsa } \\
\hline \multirow[t]{2}{*}{ FA } & CuSP & 4.794 & 2.092 & 2.292 & 0.031 & 0.009 & $2.089 / 26$ & $0.846 / 24$ & -36.534 & additive \\
\hline & $\operatorname{Pr}$ & 1.847 & 0.344 & 5.369 & $<0.0001$ & & & & & \\
\hline \multirow[t]{3}{*}{ EFA } & CuSP & 13.274 & 5.210 & 2.548 & 0.018 & & & & & \\
\hline & $\operatorname{Pr}$ & 3.863 & 0.953 & 4.053 & $<0.001$ & -0.005 & $3.791 / 25$ & $1.524 / 22$ & -38.438 & non-additive \\
\hline & 1:1 mixture & -10.542 & 21.830 & -0.483 & 0.634 & & & & & \\
\hline \multirow[t]{3}{*}{ Protein } & CuSP & .825 & 0.833 & 0.992 & 0.327 & & & & & \\
\hline & $\operatorname{Pr}$ & 0.376 & 0.133 & 2.835 & 0.007 & -0.018 & $0.597 / 44$ & $0.487 / 41$ & -69.167 & non-additive \\
\hline & 1:1 mixture & -3.987 & 2.398 & -1.663 & 0.104 & & & & & \\
\hline \multirow[t]{3}{*}{ TBARS } & CuSP & -.247 & 1.232 & -0.200 & 0.842 & & & & & \\
\hline & $\operatorname{Pr}$ & 0.736 & 0.237 & 3.111 & 0.003 & -0.021 & $6.736 / 44$ & $1.739 / 41$ & -13.705 & non-additive \\
\hline & 1:1 mixture & 33.795 & 6.337 & 5.333 & $<0.00001$ & & & & & \\
\hline
\end{tabular}



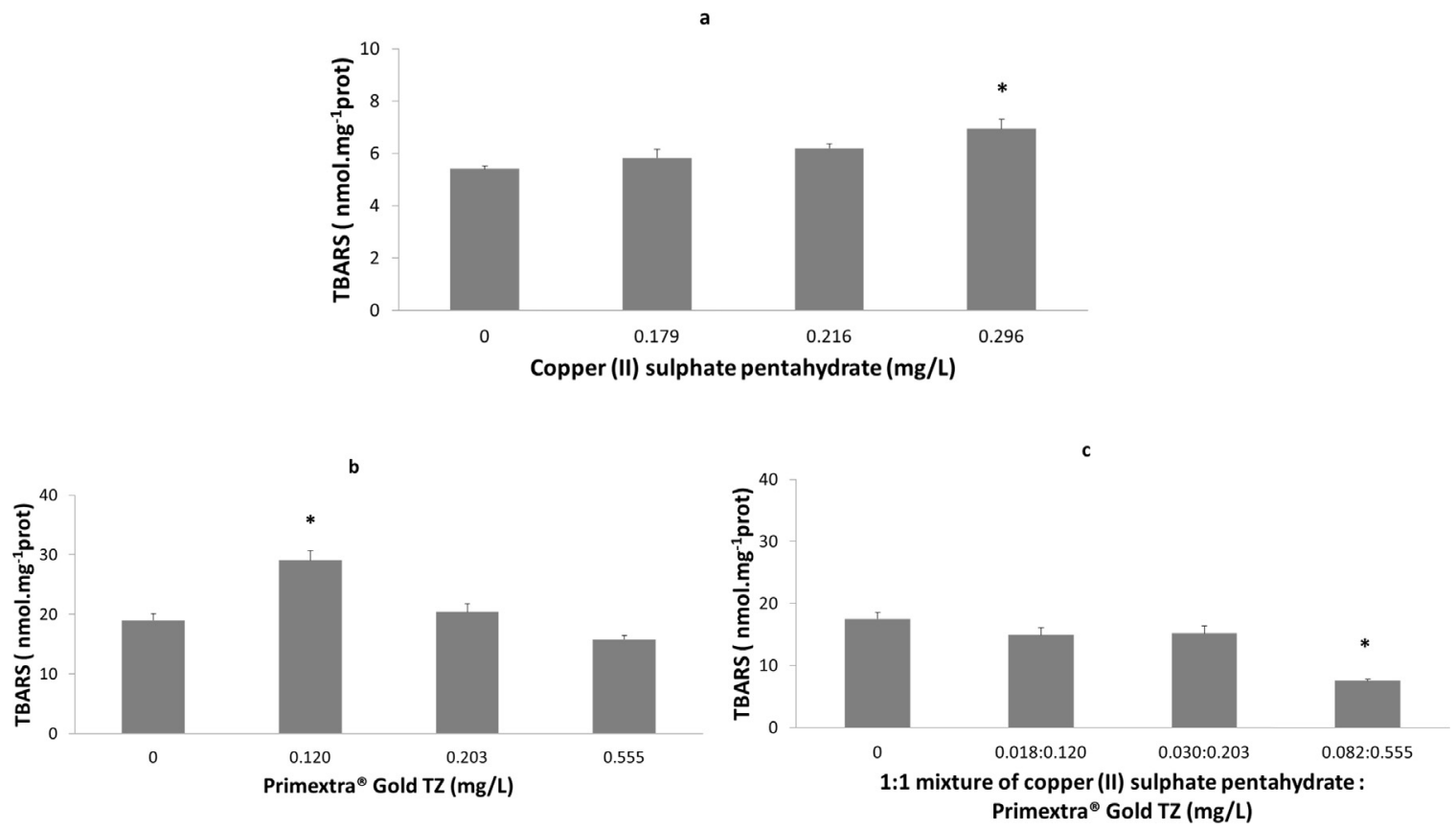

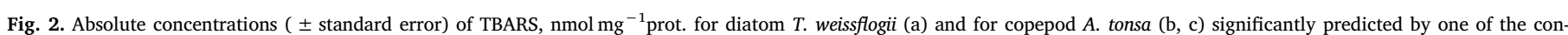

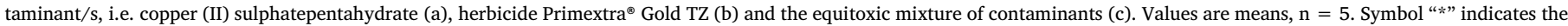
significant difference of the treatments compared to the CTL (Fig. $a-p=0.007$; Fig. $b-p=0.000$; Fig. $c-p=0.000$ ).
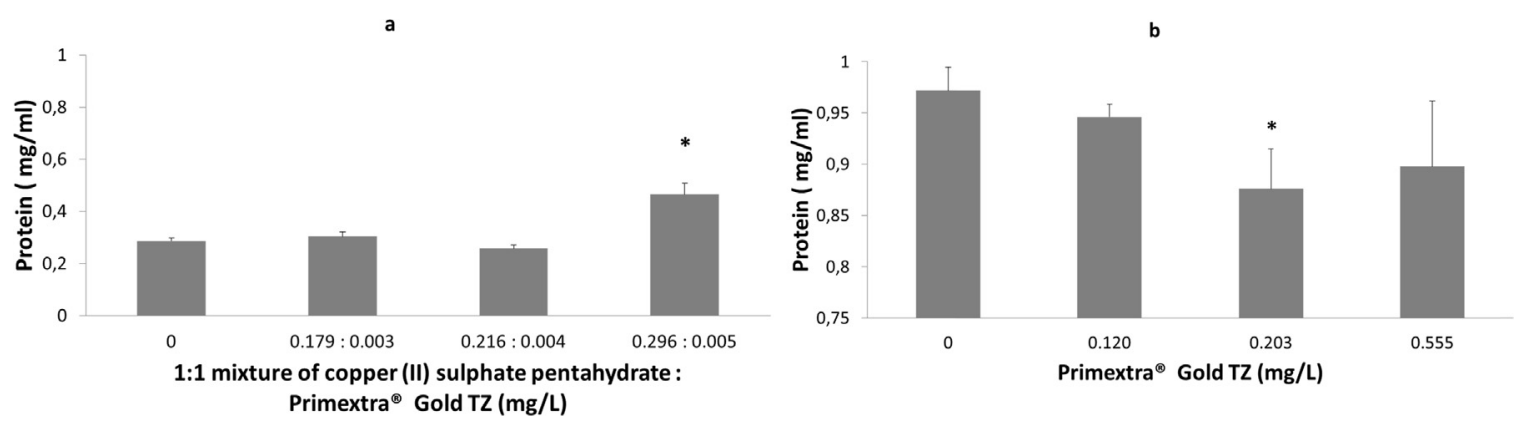

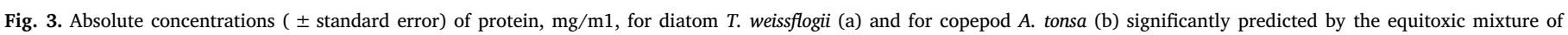

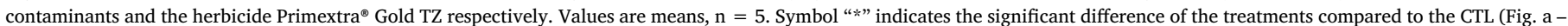
$\mathrm{p}=0.000$; Fig. $\mathrm{b}-\mathrm{p}=0.482$ ).

amount of TBARS. We hypothesize that the herbicide Primextra ${ }^{\circledR}$ generates ROS more intensively than the metal copper due to the presence of two active ingredients that subsequently lead to a greater production of MDA molecules and thus to a greater influence on TBARS content. Therefore, TBARS content was significantly predicted by the herbicide in A. tonsa. Indeed, in another study Velisek et al. (2014) showed that the activity of the antioxidant enzyme superoxide dismutase, was negatively affected in animals exposed to terbuthylazine, which can present profound impacts on production of MDA. On the other hand, another study (Mohammed, 2014) reported that a stimulatory effect of the activity of antioxidant enzymes occurred in a copepod species after being exposed to a metal (Ni). This lead to a reduction of MDA in those organisms. For the diatom T. weissflogii we assume that metal copper has a significant impact on its TBARS content due to the presence of silica in the cell wall of this species which is known to serve as a barrier to the herbicide transport (Ferreira et al., 2007). In addition, there are reports of copper excess being able to disrupt photosynthesis resulting in an increase of ROS and consequently of MDA (Bazihizina et al., 2015).

A limited number of studies on the herbicide Primextra ${ }^{\circledR}$ have shown its effect on fatty acid profiles, including the essential FA (Filimonova et al., 2016b; Gonçalves et al., 2016; Neves et al., 2015).
Effect on FA content of different marine and freshwater species was observed as well after exposure to S-metolachlor (Neves et al., 2015; Robert et al., 2007), triazine herbicides (De Hoop et al., 2013), and copper (numerous studies reviewed by Filimonova et al., 2016a).

Our modelling results revealed that nutritionally important biochemical parameters of the copepod $A$. tonsa were generally more sensitive to the chemical stressors than those of the diatom $T$. weissflogii.

This is in agreement with a few available studies that documented that the terrestrial invertebrate Eiseniafetida (Chen et al., 2015) was more sensitive to a pesticide-metal mixture (eight - component mixture of five insecticides: chlorpyrifos, avermectin, imidacloprid, $\lambda$-cyhalothrin, and phoxim; two herbicides: atrazine and butachlor; and the metal cadmium), i.e. synergism on the survival rate was observed, whereas the aquatic plant Lemna minor (Teisseire et al., 1999) and the aquatic algae Chlorella ellipsoidea (Aoyama et al., 1987) were more tolerant to organic-copper mixtures: herbicide diuron-copper and pentachlorphenol-copper respectively, i.e. antagonism on the growth rate was evident. A greater tolerance of $T$. weissflogii to the applied chemicals may be also due to the ability of diatom species generates morphological changes and activates chemical defensive mechanisms in the presence of different contaminants (Debenest et al., 2010) that finally may imply difficulties in penetration of molecules of toxicants into 

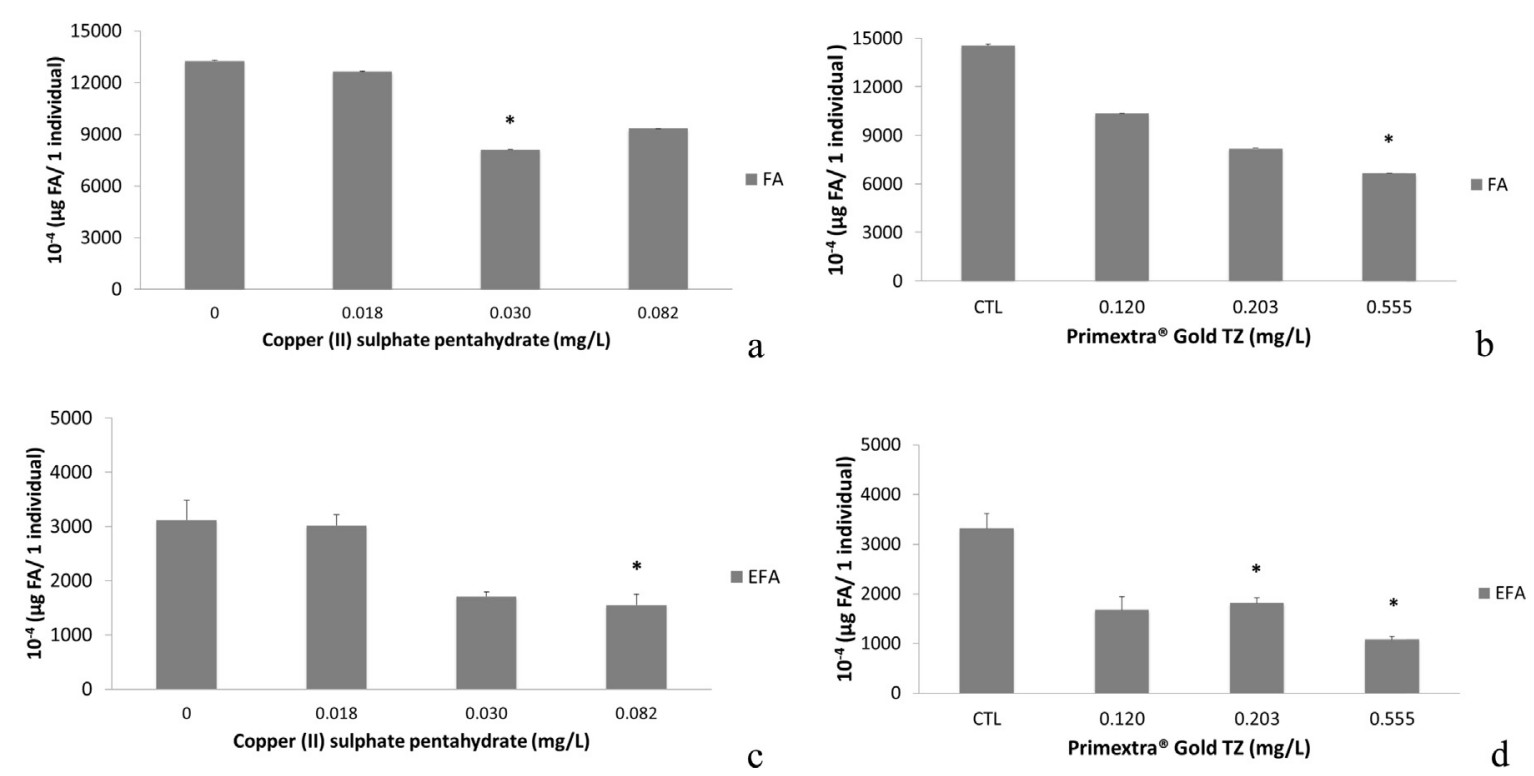

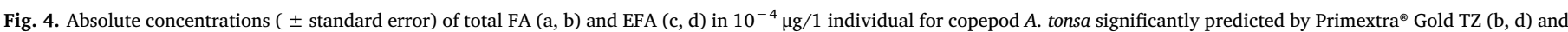

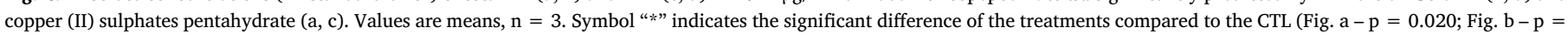
0.003; Fig. $\mathrm{c}-\mathrm{p}=0.002$; Fig. $\mathrm{d}-\mathrm{p}=0.006$ ).
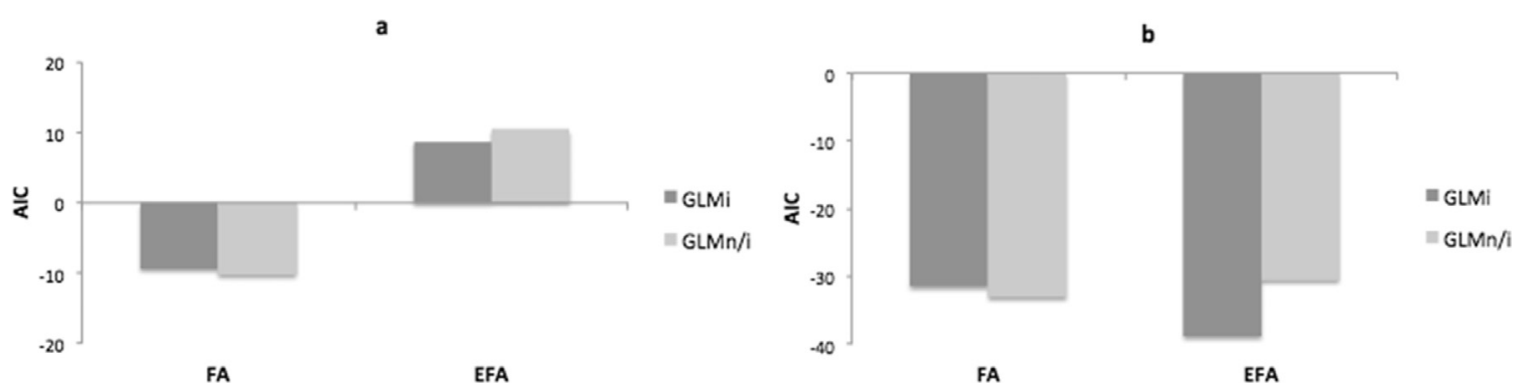

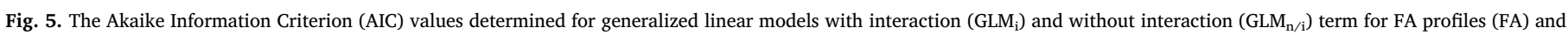

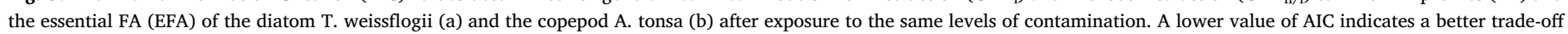
between predictive capacity and model complexity.

Table 2

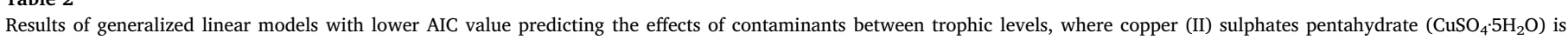

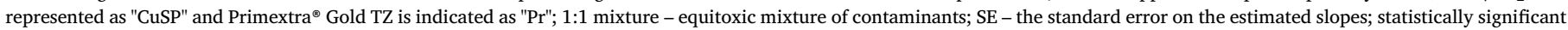
values are in bold, $\mathrm{n} / \mathrm{a}$ - not applicable.

\begin{tabular}{|c|c|c|c|c|c|c|c|c|c|c|}
\hline $\begin{array}{l}\text { Biochemical } \\
\text { parameter }\end{array}$ & Predictor & Coefficients & SE & $\mathbf{t}$ & $\mathbf{p}$ & $\begin{array}{l}\text { Median } \\
\text { deviance of } \\
\text { residuals }\end{array}$ & $\begin{array}{l}\text { Null deviance / } \\
\text { degrees of } \\
\text { freedom }\end{array}$ & $\begin{array}{l}\text { Residual deviance } \\
\text { / degrees of } \\
\text { freedom }\end{array}$ & AIC & Effect \\
\hline \multicolumn{11}{|l|}{ T. weissflogii } \\
\hline \multirow[t]{2}{*}{ FA } & CuSP & -.370 & 1.096 & -0.337 & 0.739 & -0.020 & 0.783 & 0.754 & -10.161 & additive \\
\hline & $\operatorname{Pr}$ & 0.143 & 0.165 & 0.866 & 0.395 & & & & & \\
\hline \multirow[t]{3}{*}{ EFA } & CuSP & -2.417 & 3.379 & -0.717 & 0.481 & & & & & \\
\hline & $\operatorname{Pr}$ & -0.161 & 0.528 & -0.305 & 0.763 & -0.021 & 3.038 & 2.431 & 8.648 & non-additive \\
\hline & 1:1 mixture & 20.486 & 11.296 & 1.814 & 0.083 & & & & & \\
\hline \multicolumn{11}{|l|}{ A. tonsa } \\
\hline \multirow[t]{2}{*}{ FA } & CuSP & 4.794 & 2.092 & 2.292 & 0.031 & 0.009 & $2.089 / 26$ & $0.846 / 24$ & -36.534 & additive \\
\hline & $\operatorname{Pr}$ & 1.847 & 0.344 & 5.369 & $<0.0001$ & & & & & \\
\hline \multirow[t]{3}{*}{ EFA } & CuSP & 13.274 & 5.210 & 2.548 & 0.018 & & & & & \\
\hline & $\operatorname{Pr}$ & 3.863 & 0.953 & 4.053 & $<0.001$ & -0.005 & $3.791 / 25$ & $1.524 / 22$ & -38.438 & non-additive \\
\hline & 1:1 mixture & -10.542 & 21.830 & -0.483 & 0.634 & & & & & \\
\hline \multicolumn{11}{|c|}{ Correlation between trophic levels } \\
\hline \multirow[t]{2}{*}{ SFA (A. tonsa) } & $\begin{array}{l}\text { SFA ( } T \text {. } \\
\text { weissflogii) }\end{array}$ & $-4.845 \times 10^{4}$ & $\begin{array}{l}8.498 \times \\
10^{3}\end{array}$ & -5702 & $<0.00001$ & 0.022 & 0.578 & 0.285 & -63.985 & $\mathrm{n} / \mathrm{a}$ \\
\hline & $\begin{array}{l}\text { PUFA ( } T \text {. } \\
\text { weissflogii) }\end{array}$ & $3.088 \times 10^{4}$ & $\begin{array}{l}6.328 \times \\
10^{3}\end{array}$ & 4.881 & $<0.0001$ & & & & & \\
\hline \multirow[t]{2}{*}{ PUFA (A. tonsa) } & $\begin{array}{l}\text { SFA ( } T \text {. } \\
\text { weissflogii) }\end{array}$ & $-1.691 \times 10^{4}$ & $\begin{array}{l}2.058 \times \\
10^{4}\end{array}$ & -0.821 & 0.417 & -0.039 & 1.713 & 1.673 & -0.311 & $\mathrm{n} / \mathrm{a}$ \\
\hline & $\begin{array}{l}\text { PUFA ( } T \text {. } \\
\text { weissflogii) }\end{array}$ & $5.601 \times 10^{3}$ & $\begin{array}{l}1.532 \times \\
10^{4}\end{array}$ & 0.366 & 0.717 & & & & & \\
\hline
\end{tabular}


diatom cell membrane.

In general, we conclude that the quality referring to the species at the higher trophic level (here first-level consumers) was found to be more sensitive to the chemical stressors than the one at the lower trophic level, and that the contaminants mixture mostly acted non-additively on studied biochemical parameters.

The sensitivity of the producer and the primary consumer species and the observed non-additive effect of the applied metal-pesticide mixture, on the most nutritionally important biochemical parameters, can serve to the future risk assessment of organic and inorganic chemical mixtures.

\subsection{Comparison of the effects of chemical mixture between trophic levels}

When species were exposed to the same levels of contamination, effects of the copper-Primextra ${ }^{\circledR}$ mixture on the essential FA content of both species were non-additive. These results have important consequences since essential FA $(\omega 3)$ determine the nutritional quality of algae and calanoid copepods need to take up EFA from their food source (Brett and Müller-Navarra, 1997; De Troch et al., 2012).

A healthy food web requires adequate food quality in sufficient quantities. In an aquatic ecosystem, "good" quality phytoplankton lead to better quality of zooplankton and therefore to larger and more diverse fish populations (Kelble, 2012) with high nutritional values. Aquatic organisms have been and continue to be our primary source of readily available EFA, which have proven their effects in preventing/ mitigating cardiovascular diseases, ontogenesis (particularly neural development), atherosclerosis, neural disorders, and, potentially, some cancers, as well as autoimmune diseases (Arts et al., 2001).

No significant correlation was observed for PUFA of the copepod species with SFA and PUFA of the diatom species, whereas an opposite trend was revealed for saturated FA of $A$. tonsa.

Under non-stress conditions, PUFA of the copepod species are expected to be significantly correlated with PUFA of the diatom species due to the fact mentioned above, namely that PUFA of the primary consumer species are usually taken up from food and that some PUFA (i.e. essential FA: 20:5 $\omega 3$ ) are dietary tracers between diatom and copepod species (Arts et al., 2001).

Similarly, in the absence of stressors, non-significant correlation is expected between SFA of the copepod and diatom species, since SFA (i.e. 16:0, 18:0) can be synthesized by both algae and animal cells de novo from acyl-CoA and don't depend on the food source availability.

Therefore, we conclude that the herbicide Primexrta ${ }^{\circledR}$ and the metal copper as stress factors intervened into processes of SFA's synthesis and of PUFA's transfer, including essential FA along the trophic level, i.e. primary producer - primary consumer in the case of the studied planktonic species. Indeed, the main active ingredient of Primextra ${ }^{\circledR}-$ S-metolachlor is known to inhibit FA elongase that aims to catalyze the first step of FA elongation process: the reaction of condensation of acylCoA and malonyl-CoA (Filimonova et al., 2016a; Thakkar et al., 2013). On the other hand, metal copper may bind to the thiol-group of coenzyme that interferes with the production of acyl-CoA and malonyl-CoA and therefore with SFA synthesis (Filimonova et al., 2016a).

In general, nutritionally important biochemical parameters of the primary consumer $A$. tonsa was more sensitive to the chemical stressors than of the primary producer $T$. weissflogii, when species were exposed to the equal levels of contamination. Therefore, we assume that the quality decreases when moving up the food web, which would have important implications for the human diet.

\section{Conclusions}

The major findings of this study are: (1) effects of the metal-herbicide mixture on the quality of phytoplankton and zooplankton species, were non-additive and (2) nutritionally important biochemical parameters of the species from the higher trophic level were most sensitive to the chemical stressors. This information is valuable for future riskassessment procedures of organic-inorganic contaminant mixtures, can assist in the determination of the effects for higher trophic levels (i.e. secondary consumers) and can help in the assessment of estuarine and marine ecosystem health.

\section{Acknowledgements}

This work was funded through the Erasmus Mundus MARES Joint Doctorate programme (FPA 2011-0016) (www.mares-eu.org). This study had also the support of Portuguese Foundation for Science and Technology (FCT, Portugal), through the strategic project UID/MAR/ 04292/2013, granted to MARE, and UID/AMB//50017/2013, granted to CESAM. A. M. M. Gonçalves and Sérgio M. Marques also thank FCT for financial support through the post-doctoral grants SFRH/BPD/ 97210/2013 and SFRH/BPD/112803/2015 respectively, co-funded by the Human Potential Operational Programme (National Strategic Reference Framework 2007-2013 and 2014-2020), European Social Fund (EU) and the program POPH/FSE. The FA analyses were supported by FWO-Flanders (research grant $1523814 \mathrm{~N}$ ) and by the Special Research Fund of Ghent University (BOF-UGent) in the form of the starting grant 'Energy transfer at the basis of marine food webs in a changing world', both awarded to M. De Troch.

\section{Appendix A. Supporting information}

Supplementary data associated with this article can be found in the online version at http://dx.doi.org/10.1016/j.ecoenv.2018.02.038.

\section{References}

Abdel-Tawwab, M., Mousa, M., Ahmad, M., Sakr, S., 2007. The use of calcium pre-exposure as a protective agent against environmental copper toxicity for juvenile Nile tilapia, Oreochromis niloticus (L.). Aquaculture 264, 236-246.

Aoyama, I., Okamura, H., Yagi, M., 1987. The interaction effects of toxic chemical combinations on Chlorella ellipsoidea. Toxic. Assess. Int. Q. 2, 341-355.

Arts, M.T., Ackman, R.G., Holub, B.J., 2001. "Essential fatty acids" in aquatic ecosystems: a crucial link between diet and human health and evolution. Can. J. Fish. Aquat. Sci. 58, 122-137. http://dx.doi.org/10.1139/f00-224.

Asomba, C., Ugokwe, U., 2015. Effect of herbicide (Primextra) on tissue protein levels in Clarias albopunctatus. Int. J. Pharm. Biol. Sci. 3, 145-149.

Baker, L.F., Mudge, J.F., Thompson, D.G., Houlahan, J.E., Kidd, K.A., 2016. The combined influence of two agricultural contaminants on natural communities of phytoplankton and zooplankton. Ecotoxicology 25, 1021-1032. http://dx.doi.org/10.1007/s10646016-1659-1.

Bazihizina, N., Colzi, I., Giorni, E., Mancuso, S., Gonnelli, C., 2015. Photosynthesizing on metal excess: copper differently induced changes in various photosynthetic parameters in copper tolerant and sensitive Silene paradoxa L. populations. Plant Sci. 232, 67-76. http://dx.doi.org/10.1016/j.plantsci.2014.12.015.

Bradford, M.M., 1976. A rapid and sensitive method for the quantitation of microgram quantities of protein utilizing the principle of protein-dye binding. Anal. Biochem. 254, 248-254.

Brett, M.T., Müller-Navarra, D.C., 1997. The role of highly unsaturated fatty acids in aquatic foodweb processes. Freshw. Biol. 38, 483-499. http://dx.doi.org/10.1046/j. 1365-2427.1997.00220.x.

Buege, J., Aust, S., 1978. Microssomal lipid peroxidation. Method Enzym. 52, 302-310. http://dx.doi.org/10.1088/1742-6596/71/1/012004.

Chen, C., Wang, Y., Qian, Y., Zhao, X., Wang, Q., 2015. The synergistic toxicity of the multiple chemical mixtures: implications for risk assessment in the terrestrial environment. Environ. Int. 77, 95-105. http://dx.doi.org/10.1016/j.envint.2015.01. 014.

Cohen, Z., Norman, H., Heimer, Y., 1993. Potential use of substituted pyridazinones for selecting polyunsaturated fatty acid overproducing cell lines of algae. Phtyochemistry $32,259-264$.

Cruzeiro, C., Rocha, E., Pardal, M.A., Rocha, M.J., 2016. Environmental assessment of pesticides in the Mondego River Estuary (Portugal). Mar. Pollut. Bull. 103, 240-246. http://dx.doi.org/10.1016/j.marpolbul.2015.12.013.

De Hoop, L., De Troch, M., Hendriks, a.J., De Laender, F.,, 2013. Modeling toxic stress by atrazine in a marine consumer-resource system. Environ. Toxicol. Chem. 32, 1088-1095. http://dx.doi.org/10.1002/etc.2160.

De Troch, M., Boeckx, P., Cnudde, C., Van Gansbeke, D., Vanreusel, A., Vincx, M., Caramujo, M., 2012. Bioconversion of fatty acids at the basis of marine food webs: insights from a compound-specific stable isotope analysis. Mar. Ecol. Prog. Ser. 465, 53-67. http://dx.doi.org/10.3354/meps09920.

Debenest, T., Silvestre, J., Coste, M., Pinelli, E., 2010. Effects of pesticides on freshwater diatoms. In: Whitacre, D.M. (Ed.), Reviews of Environmental Contamination and 
Toxicology. Springer Science + Business Media, LLC, pp. 87-103. http://dx.doi.org/ 10.1007/978-1-4419-0028-9.

El-Sheekh, M., Kotkat, H., Hammouda, O., 1994. Effect of atrazine herbicide on growth, photosynthesis, protein-synthesis, and fatty-acid composition in the unicellular green-alga Chlorella kessleri. Ecotoxicol. Environ. Saf. 29, 349-358. http://dx.doi.org/ 10.1016/0147-6513(94)90007-8.

Ferreira, E.A., Ventrella, M.C., Santos, J.B., Barbosa, M.H.P., Silva, A.A., Procópio, S.O., Silva, E.A.M., 2007. Leaf blade quantitative anatomy of sugarcane cultivars and clones. Planta Daninha, Viçosa-MG 25, 25-34. http://dx.doi.org/10.1590/S0100 83582007000100003.

Filimonova, V., Gonçalves, F., Marques, J., De Troch, M., Gonçalves, A., 2016a. Fatty acid profiling as bioindicator of chemical stress in marine organisms: a review. Ecol. Indic. 67, 657-672. http://dx.doi.org/10.1016/j.ecolind.2016.03.044.

Filimonova, V., Gonçalves, F., Marques, J., De Troch, M., Gonçalves, A., 2016b. Biochemical and toxicological effects of organic (herbicide Primextra ${ }^{\circledR}$ Gold TZ) and inorganic (copper) compounds on zooplankton and phytoplankton species. Aquat. Toxicol. 177, 33-43. http://dx.doi.org/10.1016/j.aquatox.2016.05.008.

Flindt, M.R., Kamp-Nielsen, L., Marques, J.C., Pardal, M.A., Bocci, M., Bendoricchio, G., Salomonsen, J., Nielsen, S.N., Jorgensen, S.E., 1997. Description of the three shallow estuaries: Mondego River (Portugal), Roskilde Fjord (Denmark) and the Lagoon of Venice. Ecol. Modell. 102, 17-31.

Gonçalves, A., Azeiteiro, U., Pardal, M., De Troch, M., 2012. Fatty acid profiling reveals seasonal and spatial shifts in zooplankton diet in a temperate estuary. Estuar. Coast. Shelf Sci. 109, 70-80. http://dx.doi.org/10.1016/j.ecss.2012.05.020.

Gonçalves, A., Mesquita, A., Verdelhos, T., Coutinho, J., Marques, J., Gonçalves, F., 2016. Fatty acids' profiles as indicator of stress induced by of a common herbicide on two marine bivalves species: Cerastoderma edule (Linnaeus, 1758) and Scrobicularia plana (da Costa, 1778). Ecol. Indic. 63, 209-218. http://dx.doi.org/10.1016/j.ecolind. 2015.12.006.

Gonçalves, A., Pardal, M.A., Marques, S.C., De Troch, M., Azeiteiro, U.M., 2010. Distribution and composition of small-size zooplankton fraction in a temperate shallow estuary (Western Portugal). Fresenius Environ. Bull. 19, 3160-3176.

Gustafson, D.I., 1989. Groundwater ubiquity score: a simple method for assessing pesticide leachability. Environ. Toxicol. Chem. 8, 339-357.

Hanazato, T., 2001. Pesticide effects on freshwater zooplankton: an ecological perspective. Environ. Pollut. 112, 1-10.

Huss, H., 1995. FAO fisheries technical paper - 348. In: Food and Agriculture Organization pf the United Nations. (C) FAO, Rome.

〈http://www.fao.org/faostat〉, (Accessed 11 November 2017).

Keegstra, K., 2010. Plant cell walls. Futur. Perspect. Plant Biol. 154, 483-486. http://dx. doi.org/10.1038/npg.els.0001682.

Kelble, C., 2012. Plankton type affects food webs. In: Tropical Connections: South Florida's Marine Environment. IAN Press, University of Maryland Center for Environmental Science, Cambridge, MD.

Klerks, P.L., Moreau, C.J., 2001. Heritability of resistance to individual contaminants and to contaminant mixtures in the sheepshead minnow (Cyprinodon variegatus). Environ. Toxicol. Chem. 20, 1746-1751. http://dx.doi.org/10.1002/etc.5620200818.

Lu, L., Wu, Y., Ding, H., Zhang, W., 2015. The combined and second exposure effect of copper (II) and chlortetracycline on fresh water algae, Chlorella pyrenoidosa and
Microcystis aeruginosa. Environ. Toxicol. Pharmacol. http://dx.doi.org/10.1016/j. etap.2015.06.006.

Martins, P.F., Carvalho, G., Gratao, P.L., Dourado, M.N., Pileggi, M., Araujo, W.L., Azevedo, R.A., 2011. Effects of the herbicides acetochlor and metolachlor on antioxidant enzymes in soil bacteria. Process Biochem. 46, 1186-1195. http://dx.doi. org/10.1016/j.procbio.2011.02.014.

Mohammed, E.H., 2014. Biochemical response of the cyclopoida copepod Apocyclops borneoensis exposed to nickel. Jordan J. Biol. Sci. 7, 41-47.

Neves, M., Castro, B., Vidal, T., Vieira, R., Marques, J., Coutinho, J., Gonçalves, F., Gonçalves, A., 2015. Biochemical and populational responses of an aquatic bioindicator species, Daphnia longispina, to a commercial formulation of a herbicide (Primextra ${ }^{\oplus}$ Gold TZ) and its active ingredient (S-metolachlor). Ecol. Indic. 53, 220-230. http://dx.doi.org/10.1016/j.ecolind.2015.01.031.

Nwani, C.D., Ifo, C.T., Nwamba, H.O., Ejere, V.C., Onyishi, G.C., Oluah, S.N., Ikwuagwu, O.E., Odo, G.E., 2014. Oxidative stress and biochemical responses in the tissues of African catfish Clarias gariepinus juvenile following exposure to primextra herbicide. Drug Chem. Toxicol. 545, 1-8. http://dx.doi.org/10.3109/01480545.2014.947503.

Perhar, G., Arhonditsis, G.B., 2009. The effects of seston food quality on planktonic food web patterns. Ecol. Modell. 220, 805-820. http://dx.doi.org/10.1016/j.ecolmodel. 2008.12.019.

Pytharopoulou, S., Kournoutou, G.G., Leotsinidis, M., Georgiou, C.D., Kalpaxis, D.L., 2013. Cadmium versus copper toxicity: insights from an integrated dissection of protein synthesis pathway in the digestive glands of mussel Mytilus galloprovincialis. J. Hazard. Mater. 260, 263-271. http://dx.doi.org/10.1016/j.jhazmat.2013.05.031.

Rand, G., 1995. Fundamentals of Aquatic Toxicology: Effects, Environmental Fate, and Risk Assessment. Taylor \& Francis, Washington, D.C.

Repetto, M., Semprine, J., Boveris, A., 2012. Lipid peroxidation: chemical mecanism, biological implications and analytical determination. In: Catala, A. (ed.), Biochemistry, Genetics and Molecular Biology. CC BY 3.0 license.

Rippingale, R.J., Payne, M.F., 2001. Intensive cultivation of the calanoid copepod Gladioferens imparipes. Aquaculture 201, 329-342. http://dx.doi.org/10.1016/ S0044-8486(01)00608-1.

Robert, S., Mansour, M.P., Blackburn, S.I., 2007. Metolachlor-mediated selection of a microalgal strain producing novel polyunsaturated fatty acids. Mar. Biotechnol. 9, 146-153. http://dx.doi.org/10.1007/s10126-006-6102-9.

Teisseire, H., Couderchet, M., Vernet, G., 1999. Phytotoxicity of diuron alone and in combination with copper or folpet on duckweed (Lemna minor). Environ. Pollut. 106, 39-45. http://dx.doi.org/10.1016/S0269-7491(99)00066-4.

Thakkar, M., Randhawa, V., Wei, L., 2013. Comparative responses of two species of marine phytoplankton to metolachlor exposure. Aquat. Toxicol. 126, 198-206. http://dx.doi.org/10.1016/j.aquatox.2012.10.002.

Velisek, J., Stara, A., Koutnik, D., Machova, J., 2014. Effect of terbuthylazine-2-hydroxy at environmental concentrations on early life stages of common carp (Cyprinus carpio L.). BioMed Res. Intern. 2014, 1-7.

Zuur, A.F., Ieno, E.N., J.Walker, N., Saveliev, A.A., Graham, M.S., 2009. Mixed Effects Models and Extensions in Ecology with R, Journal of Chemical Information and Modeling. Springer Science + Business Media, LLC, New York. http://dx.doi.org/10. 1017/CBO9781107415324.004. 